\title{
Marikana and Beyond: New Dynamics in Strikes in South Africa
}

\author{
Edward Webster, University of the Witwaterstand, South Africa
}

\begin{abstract}
Political and social change in South Africa has been crucially shaped by large-scale strikes that have often taken a violent form. In spite of South Africa establishing a constitutional democracy in $1994-$ and a new vision of industrial relations - violence has become so entangled in institutional life that South Africa has been described as a "violent democracy". The massacre of thirty-four striking workers by heavily-armed police at Marikana in August 2012 was a culmination of this trajectory. The article explores the possibility of a nonviolent resolution of industrial disputes. This would require the capability of unions to recognise and strategically use the four dimensions of union power: structural, institutional, associational and societal. Without such capabilities, power resources may go unutilised, or be strategically ineffective. The article argues that in post-apartheid South Africa, associational power has become disconnected from institutional power. Instead of a vital interaction between the two, the institutions created by the new labour regime have become disconnected from the organisations that created them.
\end{abstract}

\section{KEY WORDS}

Comparative industrial relations; Global labour; Strikes; Violence; South Africa

\section{Introduction}

One of the puzzles of post-apartheid industrial relations is the persistence of strike violence - both by police and workers - in spite of the establishment of democracy in 1994, and the avenues laid out in the new labour regime for the nonviolent resolution of conflict. ${ }^{1}$

Recent scholarship on violence in developing societies has challenged conventional views that democratic institutions necessarily lead to the observance of democratic norms. Violent pluralism, it

\footnotetext{
${ }^{1}$ My concern with strike violence is the result of two public engagements. The first, in 1989-1990, was as an expert witness giving evidence in mitigation of the death sentence for four men who had been found guilty of murdering four strikebreakers. My argument, which the court accepted, was that the accused turned to violence to enforce collective solidarity in the absence of the right to picket. The accused escaped the death sentence (Simpson and Webster, 1991). The second public engagement was in 2014 when I was invited to make an input into the seminars established by the Farlam Commission of Inquiry into the Marikana massacre. My brief was to examine alternative nonviolent resolutions of industrial conflict.
} 
is argued, may constitute a social order with its own kind of stability characterised by endemic violence, or cycles of violence (Arias and Goldstein, 2010: 9-13, 26-27). South Africa provides an example of the persistence of violence under democratic institutions. Importantly, this violence does not happen in silos. The extraordinarily high levels of domestic violence, especially against children and women in South Africa, cannot be divorced from strike violence as it is during prolonged strikes that frustrated men turn their rage towards women (Jewkes et al., 2009; Statistics South Africa, 2015). Indeed, violence is reproduced at the intersection of race, class, gender and sexuality (Lutz, Vivar and Supik, 2011; Grzanka, 2014). Thus an intersectional approach is necessary in order to understand the way in which these different dimensions of power interact to reproduce violence. ${ }^{2}$

After decades of intense struggle in South Africa, black workers won the right to strike, now entrenched in the 1995 Labour Relations Act (LRA) and in South Africa's Constitution. However, the length and violent nature of strikes over the past decade has led employers and sections of government to question the right to strike. On the one hand, some employers have suggested the need to curtail the right to strike; on the other hand, sections of the labour movement have responded defensively, arguing that the right to strike is under threat. ${ }^{3}$

There is a view, expressed in the mainstream media, that South Africa needs a Margaret Thatcher to "tame" the unions. Indeed, Thatcher's death in 2013 prompted pleas from journalists for a Thatcher-like crack-down on unions. John Kane-Berman (2013: 9), the CEO of a liberal think tank, wrote in his weekly column in South Africa's leading financial daily: "We need our own Thatcher to handle trade unions". Similarly, columnist Justice Malala (2013: 8) wrote: "We could use an iron Zulu".

While the right to strike may not be under direct threat de jure, the behaviour of all four actors during recent strikes - workers, unions, employers and government - has led to proposals that could undermine the de facto right to strike. In this article, I suggest three procedural reforms that could facilitate the voluntary and democratic construction of collective solidarity among workers. This, I suggest, could be the first step towards an alternative nonviolent approach to strikes.

${ }^{2}$ I would like to thank Karen Hurt for encouraging me to foreground the broader issue of gender-based violence in South Africa.

${ }^{3}$ The Congress of South African Trade Unions' (COSATU) research arm, the National Labour and Economic Development Institute (NALEDI), held a workshop on 10 September 2014 on the right to strike. One of the presenters argued that the right to strike was under threat because of the demand by some employers to reintroduce into the LRA the requirement that unions undertake a secret ballot before embarking on a strike. Currently, unions are required to include balloting in their constitutions, and the Department of Labour recently sent letters to unions asking how they were dealing with this requirement. Irvin Jim, general secretary of the National Union of Metalworkers of South Africa (NUMSA), saw this as an "attack on workers" right to strike" (quoted in Marrian, 2014: 3). Another potential erosion of the right to strike is declaring large numbers of economic activities as "essential services" through the National Key Points Act and restricting protests through the Regulation of Gatherings Act of 1993.

Global Labour Journal, 2017, 8(2), Page 140 


\section{A Crucial Role}

Strikes have played a crucial role in shaping South Africa's economic and political system. Most of these strikes were "demonstration stoppages" which were very effective in speeding negotiations to an acceptable outcome. However, they sometimes became "trials of strength", as both parties refused to compromise and the strike continued for days, weeks and even months (Hyman, 1972: 17-24). ${ }^{4}$ Lengthy strikes can lead to serious deprivation for strikers and their families. In such circumstances, employers' attempts to recruit replacement labour, or scabs, ${ }^{5}$ can lead to violence as strikers attempt to maintain collective solidarity. In the history of South Africa, these "trials of strength" have often impacted on the relationship between political parties and social classes, leading to a realignment of politics.

This article is divided into three parts. First, it is argued that political and social change in South Africa has been crucially shaped by large-scale strikes that have often taken a violent form. Second, in spite of South Africa establishing a constitutional democracy in 1994 - and a new vision of industrial relations - violence has become so entangled in institutional life that South Africa has been described as a "violent democracy". The massacre of thirty-four striking workers by heavily armed police at Marikana in August 2012 was a culmination of this trajectory. Third, I explore the possibility of a nonviolent resolution of industrial disputes. I suggest this would require the capability of unions to recognise and strategically use the four dimensions of union power: structural, institutional, associational and societal (Lévesque, and Murray, 2010). ${ }^{6}$ Without such capabilities, power resources may go unutilised, or be strategically ineffective. Union power needs both resources and capabilities to foster the renewal of their capacity to successfully increase, activate and represent their membership. I argue that in post-apartheid South Africa, associational (or organisational) power has become disconnected from institutional power. Instead of a vital interaction between the two, the institutions created by the new labour regime have become disconnected from the organisations that created them.

But the challenges facing a union renewal strategy are huge; structural violence is embedded in South Africa's violent past. We are an example of what Douglas North (1990) calls path dependence: the founding institutions of a country are a fundamental determinant of its growth path (Webster, 2013: 210-211).

I conclude by arguing that, if used strategically, strikes have the potential to create a space for non-zero-sum gains where workers and capitalists are better able to realise their interests than is

\footnotetext{
${ }^{4}$ For example, the 2013 Medupi Power Station strike lasted five months; the platinum strike in 2014 lasted five months; and the strike in the metal industry in August 2014 lasted five weeks.

5 The popular term in South Africa for scabs is amagundwane. It means rats.

${ }^{6}$ Lévesque and Murray (2010) identify the following strategic capabilities as being of particular significance for the mobilisation of union power: the capacity to develop a collective interest (consensus building); framing and defining a proactive and autonomous agenda; linking the local and the global across space; and fostering the ability to learn and to diffuse learning throughout the organisation.
} 
possible by simply extracting concessions through confrontation (Wright, 2013). ${ }^{7}$ Wright calls this a positive class compromise; Przeworski (1985: 171-203) calls it optimal militancy - a militancy which does not discourage capital from investing and ensures workers get a fairer share of their labour.

\section{Part One: Trials of Strength and Political Realignment}

Three strikes - trials of strength - can be identified as turning points in South African history. First, the 1922 white mineworkers' strike went on for three months and brought South Africa to the brink of civil war. Law and order was only restored when Jan Smuts, prime minister of South Africa at the time, summoned the newly formed South African Air Force to bomb white working-class suburbs such as Benoni and Germiston from the air. A government inquiry reported the casualties as 153 killed and 687 injured; four men were executed for treason (Webster, 1978: 14). The outcome of the strike was a class alliance between the emerging Afrikaner nationalist movement and white labour. This alliance laid the foundations for modern South Africa's white protectionist labour regime.

The 1946 African mineworkers' strike marks a second turning point. World War 2 had seen a surge of strikes by African workers and a rapid increase in the growth of African unions, including the establishment of the African Mine Workers' Union (AMWU) in 1941. In 1946, AMWU called for

immediate steps to provide adequate and suitable food for the workers and, in accordance with the new world principles for an improved standard of living, subscribed to by our Government at the United Nations, an increase in the minimum wage for all African mine workers at one pound a day (cited in Webster, 1978: 17).

The demand was ignored, and a four-day strike followed. Nine men were killed and more than 1200 injured. The strike highlighted the growing urbanisation of African workers. Afrikaner nationalists used this "threat" to help them win the 1948 general elections, which they contested on a programme of white domination. Importantly, it also led to an alliance between black labour and African nationalism. This alliance culminated in the formation of the Congress Alliance in 1955 between the African National Congress (ANC) and the recently formed South African Congress of Trade Unions (SACTU) (O’Meara, 1975).

The third turning point was the mass strikes of black workers in Durban in January and February 1973. These strikes happened during the high point of apartheid, a time when it was widely believed that strike action was not possible in apartheid South Africa. Remarkably, there was no police violence. Instead, the strikes laid the foundation for the modern labour movement. Trade unions were established after these strikes in all the major metropolitan areas of South Africa. These

\footnotetext{
${ }^{7}$ In an International Labour Organisation (ILO) report on the National Economic Development and Labour Council (NEDLAC), South Africa's premier social dialogue institution, we criticised the social partners for using the forum in an instrumental way. We recommended that NEDLAC's role is to provide an independent space for all the partners to develop a common vision on the way forward in the wake of the Marikana massacre of August 2012 (Webster, Joynt and Metcalfe, 2013).
} 
emerging unions approached employers, and later the apartheid state, cautiously first by winning recognition for their embryonic organisations at plant level before gradually establishing nationwide industrial unions. This led to the reform of the industrial relations system in 1979, allowing for the formal recognition of trade unions for black workers and their right to join the established collective bargaining system.

If the 1973 strikes led to the reconfiguration of the industrial relations system and the emergence of an independent workers' movement for the first time in South Africa, it was the massacre of thirty-four striking mineworkers on 16 August 2012 at Marikana that called into question the sustainability of the new post-apartheid order (Alexander et al., 2012). What was the nature of this new industrial relations order?

During the 1980s, a pattern of violence emerged in workplaces where workers were not represented adequately by unions, where management was intransigent, and where police were perceived to be cooperating with employers. Workers would become frustrated with the lack of attention to their grievances and lose faith in the negotiation process. Individuals would start to violently "police" the strike; the strike would be prolonged and confrontation would follow (Simpson and Webster, 1991). A regularly employed township resident remarked:

I think that anyone or everyone who grew up in a township [knows that] if you don't cooperate with the comrades ... either they burn you or they beat you up ... The police also shot at people because they couldn't tell if you were really going to work or you were only one of the comrades (quoted in Alexander and Pfaffe, 2013: 15).

Out of this conflict, a new vision for industrial relations emerged, drawing on some of the key characteristics of a coordinated market economy (CME). In particular, the right to strike was constitutionalised and the right to picket was included in the 1995 Labour Relations Act, which was the cornerstone of the new vision. It had five key features (Webster, 1999: 46-47):

- The LRA brought all employees into one industrial relations system for collective bargaining in Bargaining Councils (previously Industrial Councils). It extended the right to participate in Bargaining Councils to farm, domestic and public-service sectors (except the security services).

- The LRA promoted collective bargaining - although it did not make it compulsory - by guaranteeing organisational rights to unions in the workplace:

○ providing unions with access to employer premises],

○ meeting rights,

- union subscription facilities with the right to conclude closed shops under certain conditions,

- protecting employees' right to strike, with a clear right to picket and to engage in sympathy strikes.

- The LRA dramatically overhauled dispute resolution procedures through the establishment of a state-funded and independent Commission for Conciliation, Mediation and Arbitration (CCMA). Its purpose was to resolve disputes, initially through conciliation, with the right to 
impose compulsory arbitration in the case of unfair dismissals or "essential services", or to arbitrate if a dispute was referred to it. Through such interventions it was hoped that the CCMA would "reduce the frequency of strikes" (Webster, 1999: 22).

- The LRA established clear rules on dismissals so they would no longer be decided by expensive and time-consuming litigation in the Industrial Court. The Act envisaged that most cases regarding alleged unfair dismissal, severance pay issues and organisational rights would be decided by arbitration. However, where arbitration failed, parties could be referred to a new Labour Court which, replacing the Industrial Court, would have powers equal to those of the Supreme Court.

- The LRA introduced workplace forums. A forum could only be established after a representative trade union applied for it to the CCMA. Forums were only considered in workplaces with more than 100 employees. The purpose of workplace forums was to extend the potential for codetermination.

The LRA was subsequently supplemented by three other Acts. First, the Basic Conditions of Employment Act (BCEA) of 1997 aimed to regulate minimum conditions of employment and ensure that working conditions of unorganised and vulnerable workers complied with minimum standards as defined, among others, by the International Labour Organization (ILO) (Venter and Levy, 2011: 225-235). Second, the Employment Equity Act (EEA) of 1998 sought - against the racially discriminatory background of apartheid - to promote equal opportunities in the workplace by eliminating unfair discrimination in employment practice or policy (Venter and Levy, 2011: 236240). Third, the Skills Development Act (SDA) of 1998 aimed to improve the skills of the South African workforce by improving investment in training and development (Venter and Levy, 2011: 246-247).

The introduction of a new labour regime was a major step towards a more inclusive and participatory industrial relations system. Indeed, South Africa was celebrated globally for its "miracle" victory over apartheid, and praised by the ILO for its successful transition to a more rights-based and cooperative industrial relations system. Some innovations, such as the workplace forums, did not take off because workers already had workplace representation through shop steward committees. But vulnerable workers such as public sector, domestic and farm workers, who were previously excluded from the industrial relations system, now had the same rights as all other workers.

Although new labour legislation was passed and innovative institutions introduced that laid the foundations for a corporatist-style industrial relations system through NEDLAC at the macro level, through centralised bargaining at the meso level, and through workplace forums at the micro level, the conditions for successful corporatism have not been realised in post-apartheid South Africa (Webster, 1999: 47-48). The process of elite-pacting that led to South Africa's "negotiated revolution" essentially conserved the pillars of the apartheid economy - the Minerals Energy Complex (MEC), a set of interlocking institutions that ensured continuity of the apartheid developmental path (Adler and Webster, 1995; Fine and Rustomejee, 1999; Bond, 2000).

Initially, the new labour regime seemed to be successful. Strike action dropped, reaching a low 
of 850000 days in 1997. Innovative labour market institutions such as the CCMA were seen to be doing an excellent job. From 2005, however, strike action began to increase dramatically, reaching 14.6 million working days lost by 2010. Strikes became trials of strength, continuing over longer periods of time, and became increasingly violent (see Table 1).

Table 1: Workdays lost through strike action, 1996-2014

\begin{tabular}{|c|c|c|}
\hline Year & $\begin{array}{l}\text { Year total (millions) of } \\
\text { working days lost } \\
\text { through strike action }\end{array}$ & $\begin{array}{l}\text { 2nd quarter (millions) of } \\
\text { working days lost } \\
\text { through strike action }\end{array}$ \\
\hline 1996 & 1.70 & 0.04 \\
\hline 1997 & 0.85 & 0.28 \\
\hline 1998 & 2.30 & 0.31 \\
\hline 1999 & 3.10 & 0.41 \\
\hline 2000 & 0.50 & 0.12 \\
\hline 2001 & 1.25 & 0.23 \\
\hline 2002 & 0.94 & 0.13 \\
\hline 2003 & 0.70 & 0.24 \\
\hline 2004 & 1.10 & 0.22 \\
\hline 2005 & 2.30 & 0.71 \\
\hline 2006 & 2.90 & 1.60 \\
\hline 2007 & 12.90 & 11.50 \\
\hline 2008 & 0.98 & 0.28 \\
\hline 2009 & 2.90 & 0.53 \\
\hline 2010 & 14.60 & 1.25 \\
\hline 2011 & 6.20 & 0.40 \\
\hline 2012 & 3.50 & 0.70 \\
\hline 2013 & 5.20 & 1.87 \\
\hline 2014 & & 7.50 \\
\hline
\end{tabular}

Source: Andrew Levy (2014: 3)

In 2006, a strike in the private security industry lasted for three months and led to fifty-seven deaths. As one worker remarked:

There is no sweet strike; there is no Christian strike ... A strike is a strike. You want to get back what belongs to you ... You won't win a strike with a Bible. You do not wear high heels and carry an umbrella and say '1992 was under apartheid, 2007 is under ANC'. You won't win a strike like that (quoted in Von Holdt, 2O1O: 141). 
The Marikana massacre had an immediate impact on political life. The launch of the left-wing racial populist Economic Freedom Front (EFF) in 2013, and its ability to win over one million voters in the April 2014 general election, and over two million in the August 2016 local government elections, has had a dramatic impact on Parliament. There they have put the ANC, and President Zuma in particular, on the defensive and have also overshadowed the official opposition. The decision in December 2013 by the National Union of Metalworkers of South Africa (NUMSA), COSATU'S largest affiliate, not to provide organisational support to the ANC in the general elections, its expulsion from COSATU in November 2014, and its decision to explore the idea of a United Front, was the first major challenge from inside COSATU to the hegemony of the ANC and the South African Communist Party (SACP) .

Designed to link unions to struggles in the community, a National Working Committee of the United Front was established in December 2014. Although no progress has been in formally launching the United Front, it had at the time an estimated 250 loosely associated social justice and environmental justice affiliates. Of particular concern are climate change issues and the demand for eco-socialism. However, its political direction remains uncertain: should it be openly socialist, or a broad front similar to the United Democratic Front (UDF) of the 1980s? Is it a step towards a workers' party, or is it an autonomous body connecting a range of community-based organisations? Should it engage in electoral politics, or should it remain at arms' length from party politics?

Importantly, the multiple expressions of local-level militancy which emerged over the past decade have indicated a fragmented militancy, different from the social movement unionism of the early to mid-eighties (Webster, 1988). The link between the current township protests and NUMSA is tenuous. Indeed, the high level of unemployment in these communities - sometimes as high as 80 per cent - has led to conflicts and intensified violence between the employed, who are trying to maintain collective solidarity in a strike, and those who want to go to work. This emerged most dramatically in the strikes on the platinum mines in Rustenburg. The coercive tactics that the mineworkers used to maintain solidarity have been described by Chinguno as a form of "violent solidarity" (Chinguno, 2015: 178).

It is important to emphasise that the new initiatives, organisational forms and sources of power are emerging on the periphery of organised labour. The strikes at Marikana were not led by a union but were the product of the self-activity of labour, as Sinwell and Mbatha argue:

The agency of workers, and more specifically the independent worker's committee, is arguably the key feature surrounding the event of the Marikana Massacre ... The committee at Marikana is important in understanding the strike wave along the Rustenburg Platinum Belt where these independent organizations emerged. Industrial sociology more generally has been dominated by investigations into formalized unions... (Sinwell and Mbatha, 2013: 32)

Whether the events triggered by Marikana will lead to a full-scale realignment of political parties in South Africa remains to be seen, but what is clear is that political forces outside of the dominant ANC-led Alliance are presenting a direct challenge to their hegemony for the first time in postapartheid South Africa. 


\section{Part Two: South Africa: A Violent Democracy}

Karl von Holdt (2013a: 15) has taken recent scholarship on violence in developing societies a step further by speaking of the "nexus of democracy, patronage and violence" as constituting a form of "violent democracy". He argues that:

Democratic institutions and processes generate violence as disputes and conflicts are mediated both within and outside of them, and the forms that violence takes are shaped by these institutions and processes, differing from the forms it takes in authoritarian regimes. ... democracy shapes the forms that violence takes, but on the other hand it also constrains violence and provides new means in the struggle to curb and hold accountable the purveyors of violence (Von Holdt, 2013a: 15).

Von Holdt cites the case of Marikana, where the official Commission of Inquiry, the Farlam Commission, was able to hear evidence from a range of individuals and organisations. Furthermore, the existence of an independent judiciary, a free press and civil society organisations ensured that incriminating evidence of police violence entered the public domain and could lead to serious consequences for those found guilty of criminal violence. ${ }^{8}$

The targeted assassinations of local trade union leaders intensified with the rise of the Association of Mineworkers and Construction Union (AMCU), a rival to the COSATU-aligned National Union of Mineworkers (NUM), to majority status in the platinum sector. ${ }^{9}$ However, there is evidence that this pattern of shootings existed inside NUM prior to AMCU's breakaway (Von Holdt, 2013a: 10). Democracy creates new opportunities for union leaders and shop stewards, raising the stakes in union elections and the potential for rivalry to take a violent form. "Violence", Von Holdt (2013a: 11) concludes, "is produced by democratic institutions and at the same time constrains their democratic potential. Democracy and violence are entangled and mutually shaping processes." Importantly, Von Holdt (2010: 149) locates these "local moral orders" that legitimise violence in the wider context of an unjust and highly unequal social order.

Von Holdt has developed a convincing argument for interpreting this pattern of violence as part of intra-elite struggles for positions and power (Von Holdt, 2010; 2013a, 2013b). However, as often happens in the social sciences, it is possible to interpret the evidence in different ways. Peter Alexander (2010) has described these protests as being part of a wider "rebellion of the poor". The words "poor" and "rebellion" are crucial in Alexander's argument. He distinguishes between the poor - who are unemployed or in casual work and living in townships - from those in regular

\footnotetext{
${ }^{8}$ By September 2016, over four years after the massacre, there still had been no prosecutions of the police involved. Instead, the head of the police was being investigated for criminal offences.

${ }^{9}$ Buhlungu (2001), drawing on Robert Michel's "iron law of oligarchy", demonstrates the growing distance of full-time trade union officials from their members as these organisations grew in size and attempted to "modernise". This growing social distance between leaders and led has fuelled union breakaways.
} 
employment. The term rebellion is also crucial, as Alexander shows how these protests differ from a strike that is directed at employers: these protests are directed at the local state, and at elected councillors in particular.

However, unlike the 1980s when community organisations formed alliances with the trade union movement, the widespread and intense protests since 2005 have not yet led to joint unioncommunity action. In spite of a perceived decline in the delivery of services, participation in community service delivery protests has declined, according to surveys of COSATU members. In an analysis of this data, Sarah Mosoetsa (2012: 163) explains this lack of labour-community links as being due to "COSATU members' prioritization of shop floor and labour market concerns - better wages, job security and employment creation - over the issues of service delivery by the government". She concludes with this observation:

Given the historical role that COSATU and its members played in many communities during the struggle against apartheid, including its strategic linking of township political struggles with shop-floor demands, many would expect that community participation (in local government structures or community protests) would be one of the top items on COSATU's agenda (Mosoetsa, 2012: 163-164).

Implicit in Mosoetsa's observation is a critique of the growing distance between members of trade unions and the growing number of working people outside the ranks of trade unions. In the 2004 COSATU Workers Survey, 91 per cent of COSATU members were drawn from the core of permanent, full-time workers (Bhulungu, 2006). I argued at the time that the federation was facing a "crisis of representation" (Webster, 2005: 23). COSATU has now embarked on an attempt to recruit vulnerable workers into the federation, and imaginative strategies are emerging from the task team set up to explore possible strategies to expand its membership (Barrett, 2016). ${ }^{10}$

Importantly, and often overshadowed by the Marikana massacre, were the uprisings in the rural areas of the Western Cape in late 2012 and early 2013. Farm workers broke the widely held assumption that they were "un-organisable" because they were "smothered" by paternalism and could only resist with the "weapons of the weak" (Wilderman, 2017: 3). In a fascinating account of the uprisings, Jesse Wilderman shows how the shift away from permanent, on-farm labour to a more seasonal, off-farm and migrant labour force living in crowded informal settlements transformed worker identity, overcame the isolation of farm labour, and opened up new sources of power, leading to joint action between "the poor" in these areas and farm workers (Wilderman, 2017). This collective action of workers in an informal alliance with casual workers and the unemployed is historic, marking the first large-scale example of joint worker and "community" action in postapartheid South Africa.

I suggested in the previous section that the impact of major strikes - trials of strength - have

${ }^{10}$ In December 2015, the coordinator of this task team, Jane Barrett, resigned from COSATU. The initiative has been moribund since she left.

Global Labour Journal, 2017, 8(2), Page 148 
historically led to the realignment of politics. These strikes were the result of labour's capacity to disrupt production in the heart of the economy through the withdrawal of their labour. Erik Wright (2000) has described this as structural power - power in the heart of the economy - and distinguishes it from organisational or associational power - the ability to organise collectively into trade unions or political parties. For a strike to succeed, workers also need the support of their communities - what could be called societal power. However, if these sources of power are to be consolidated, certain "rules of the game" need to be established through legislation (labour law) and through institutions. This has been called institutional power (Dörre, Holst and Nachtwey, 2009). Reconnecting organisational/associational power to institutional power, I would argue, is at the heart of building an alternative to violent strikes.

Institutional power embeds past social compromises through the incorporation of associational, structural and societal power into institutions (Dörre et al., 2009). As McGuire (2012) argues, this source of power continues to be applied during ongoing economic cycles, even where power relations within society may have changed. ${ }^{11}$ It may take the form of labour law, wage setting and bargaining arrangements, or institutionalised forms of social dialogue, such as NEDLAC (McGuire, 2012: 43). The important point about institutional power is that it grants rights but also limits the space for action (Dörre et al., 2009).

The Jena power resources approach (Dörre et al., 2009) argues that institutions shape the relationship between structural and associational/organisational power. But, they argue, power resources are not sufficient; they need strategic capabilities such as the capability to detect power resources in order to make use of them, and the organisational flexibility to optimise associational power. In post-apartheid South Africa, the organisations which created the new labour regime have become disconnected from the institutions they created. As illustrated in Figure 1, there should be a vital interaction between organisational/associational power and institutional power. It is only through interaction between the two sources of power that leadership can keep in contact with its members.

Let me now turn to the difficult question of whether there is a nonviolent alternative way of resolving industrial disputes in a "violent democracy" such as South Africa.

\footnotetext{
${ }^{11}$ In her doctoral thesis at the University of Kassel, Donna McGuire (2012) develops the fact that institutional power is a neglected dimension of power.
} 


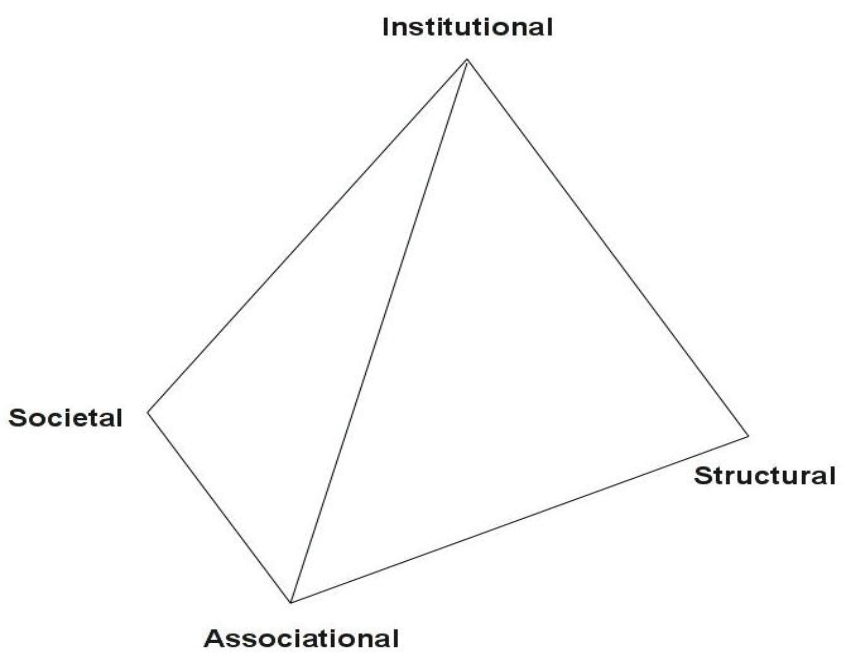

Source: Brinkmann et al. (2008: 364)

Figure 1: The pyramid of workers' power resources

\section{Part Three: Is There a Nonviolent Workplace Alternative?}

Is it possible for collective solidarity among workers - a necessary condition for a successful strike to be constructed by voluntary and democratic means? It is worth noting that the overwhelming majority of "demonstration stoppages" are nonviolent; violence seems to occur where the parties become intransigent, and a "trial of strength" follows.

At the centre of an alternative approach must be workers' sense of having democratic control of the strike. This includes confidential balloting of members before and during the strike, an effective picket and a strike fund to maintain the stability of households during the strike. Above all, it requires a democratic union in regular communication with its members, restraint on the part of the police, and a management willing to negotiate (Simpson and Webster, 1991). ${ }^{12}$

At the centre of this alternative avenue are three conditions. First, unions undergoing a strike

${ }^{12}$ Clearly these proposals only apply in situations where a union already exists. In many situations discussed in this article there were no representative unions. That is why I am not suggesting that balloting should be made mandatory by law; rather, it should reflect a voluntary commitment to workers' control. In situations where no established union exists but where there are embryonic workers' committee, then a mass meeting with a show of hands is probably the most effective way of establishing popular support for a strike. My proposals are aimed at suggesting ways of revitalising existing unions. In some cases, workers may be scattered, as in the retail sector. A ballot could be a way of bringing members together in these circumstances and, of course, it is always possible to use electronic voting through a short messaging service (SMS). 
need to undertake a confidential ballot. The idea of a ballot has been discredited because employers used it during the apartheid period as a way to interdict strikes on the basis that the ballot procedures were in some way defective (Du Toit et al., 2003: 288). I argue that it should not be reintroduced into the Act, as some employers argue; instead, it should be voluntary and an indication of the union's commitment to worker control by their members. ${ }^{13}$ Such a ballot should take place at the workplace, be conducted by professional electoral officers, and in the presence of management. ${ }^{14}$ The great advantage of this for both parties is that it nudges employers to settle before resorting to a strike. It acts as an early warning mechanism. For example, 50000 workers were balloted in SACTWU in 2013, and 85 per cent of them supported a strike. A strike was pre-empted when employers settled.

A secret ballot ensures that the union has a democratic mandate for a strike and, if necessary, further ballots can be held during the negotiations, especially when provisional agreement is reached. Importantly, it should be an internal requirement in the union, not a statutory requirement of the LRA. As Andre Kriel, general secretary of SACTWU observes: "We always voluntarily ballot our members before embarking on a wage strike action. It is part of our internal policy of worker control on critical organisational matters (Kriel, interview, February 2014).

A second condition for a nonviolent strike is the existence of a union strike fund. This may sound counterintuitive. Would having a strike fund not prolong the strike even further, sceptics may ask? The evidence, however, suggests the opposite. To build a significant strike fund, rather than embarking on a last-minute fundraising activity, requires the union to plan strategically by regularly collecting money for the strike fund from its members over a period of five to ten years to create what the Germans call a "war chest". Since it is workers' money, the pressure is on the union to take full responsibility for the strike. Although COSATU has passed resolutions to develop such a fund, it has not materialised. This, in spite of the existence of monies in some of the more successful union investment companies. ${ }^{15}$ Importantly, a strike fund could limit the widespread domestic violence that takes place during prolonged strikes as the household tries to meet its financial obligations - to pay the rent, to pay the school fees, to feed the family, and so on. ${ }^{16}$

${ }^{13}$ A provision for confidential ballots to be compulsory if a strike is to be legal was removed from the Labour Relations Amendment Bill in 2015 after fierce resistance by COSATU. "The decision to go on strike based on the majority of the union members who have been balloted is the business of the union", said Sdumo Dlamini, president of COSATU. "We are not opposed to balloting before a strike, but we are opposed to the way it is proposed by the Minister" (Ensor, 2016: 2).

${ }_{14}$ At present, the only COSATU union affiliate that utilises this procedure is the South African Clothing and Textile Workers Union (SACTWU).

15 Apparently, some unions have developed strike funds at the local level. Further research is required on where such examples exist and how effective they are in sustaining strikers' families during prolonged strikes. The million rand that AMCU donated to its members during the five-month-long strike at Lonmin in 2014 would have provided each striking member with a mere once-off R20 grant.

${ }^{16}$ To date, evidence on domestic abuse is largely anecdotal but it calls for a serious study. Clearly, a strike fund is unlikely to eliminate domestic violence but it could become the basis of a focus on the role of men in gender-based violence.

Global Labour Journal, 2017, 8(2), Page 151 
This raises the difficult question of how workers on prolonged strikes survive in the context of the lack of a strike fund. In most cases, it seems as if striking workers survive through charitable acts of their neighbours and contributions form churches and nongovernmental organisations. This incident, drawn from an account by a journalist on how a striking Lonmin miner's wife helped a woman and others affected by the strike survive by setting up a soup kitchen, is revealing:

Seipati (the wife of a striking Lonmin miner) started a soup kitchen during the strike when she saw a woman coming from the clinic fall in the street. The woman had not eaten in three days. Hundreds of people started lining up at her house and she used her husband's pension money, with some sponsorship from the churches, to feed them (Nicolson, 2014: n.p.).

A third condition is a picketing agreement with management, where the union is required to notify the company in writing that it intends to call a picket. ${ }^{17}$ The agreement must state where the picket is to be held, the nature and duration of the picket and the steps that will be taken to ensure it is peaceful. For example, workers may not block any entrance or exit to the company. Such an agreement requires the union to take reasonable steps to ensure no one intimidates other people, damages property or carries dangerous weapons. As a leading human resource manager remarked:

A key factor in a peaceful picket is the preparation the employer puts into the picket. My experience is that it is best to conclude picketing agreements as close to the site of the protest as possible. This forces an engagement with the union and the management of the site over where the picket will take place, what is appropriate picketing and how the situation will be (Anonymous, interview, February 2014). ${ }^{18}$

It may be argued that striking workers no longer put pressure only on workers at work. They visit workers' homes, often at night, to threaten and, in some cases, assault or even murder workers who are acting as scabs. This points to the fact that for many workers and their families living conditions remain untransformed; many are migrants, living in squalid and unsafe conditions, without the promise of clean water, proper sanitation and regular electricity.

If the cycle of strike violence is to be broken, South Africa needs to address the deeper "structural violence" that lies at the heart of these strikes. There is evidence that ordinary people are losing faith in the promise of Nelson Mandela's democracy of 1994 and the institutions that

${ }^{17}$ Section 69 (1) and (2) of the Labour Relations Act lays the ground rules for a protected picket. In addition, NEDLAC has issued a Code of Good Practice on picketing to provide practical guidance to those organising - or taking part - in a picket. This also applies to employers, employees or members of the public who may be affected by the strike.

${ }^{18}$ In some cases, employees in shopping malls have been prevented from picketing in front of a store. This on the grounds that it is not the store owner's property, since they are merely renting the space from the landlord who owns the shopping mall.

Global Labour Journal, 2017, 8(2), Page 152 
underpin this compromise (Thakali and Merten, 2015; Lekalake, 2016). Douglas North's (1990) proposition of path dependence states that the founding institutions of a country are a fundamental determinant of its growth path. For North, history matters not only because we can learn from the past, but also because the present and the future are connected to the past by the continuity of institutional change. He points out that institutional patterns are self-reinforcing even when they are socially inefficient. Once development has been set on a particular course, organisational learning, cultural habits and mental models of the social world reinforce that trajectory. South Africa, I suggest, illustrates North's proposition: founded on colonial conquest, violent land dispossession and patriarchy, the interlocking apartheid institutions of cheap black migrant labour based on extractive industries - the Minerals and Energy Complex - reinforce this trajectory, ensuring continuity beyond the change in political regime (Fine and Rustomjee, 1996). Crispen Chinguno, in his analysis of Marikana, concludes:

Collective bargaining alone cannot address the expectations of workers in a context of precariousness and fragmentation. Precarious work and living conditions, and the failure of political citizenship, undermine industrial relations institutions which have little capacity to manage industrial conflict (Chinguno, 2013: 165).

\section{Conclusion}

I have suggested that the legal right to strike is not under direct threat in South Africa, although the duration and violence accompanying strikes have led to calls for greater control over unions. What is at stake, then, is how the strike weapon is to be used by workers, and how employers and the state are to respond to the demands that emerge from these strikes. This requires an intersectional approach involving a re-examination of how the demands generated in these strikes could contribute to the peaceful and democratic transformation of the South African workplace and the conditions that sustain and reproduce it.

I have suggested, as a step in that direction, that unions commit themselves to a process of peaceful picketing, confidential balloting and the development of a strike fund. If workers exercise democratic control of the strike, the possibility of strike violence will be reduced and the union is more likely to take responsibility for the consequences of the strike. In this way, strikes could be used more strategically and employers could respond more constructively. This would ensure the changes brought about by collective action take the transformation process forward to a more inclusive growth path - a path that does not discourage capital from investing; and ensures that workers get a fairer share of the fruits of their labour.

This approach to strikes is usually associated with collaboration and opportunism of worker leaders. It is useful, however, to distinguish between what Erik Wright (2013) calls "negative class compromise" and "positive class compromise". Wright suggests that:

Negative class compromise refers to a situation in which there is a kind of balance of opposing class forces, each capable of inflicting considerable costs on the other, but neither capable of 
decisively defeating the opponent. ... 'Compromise' in this case means that the outcome of struggles for each party falls somewhere between complete victory and complete defeat (Wright, 2013: 13).

Positive class compromise means something quite different.

In a positive compromise, in spite of their opposing interests, the contending forces find a way to actively cooperate in ways that open up some space for non-zero-sum gains. Active forms of mutual cooperation help both workers and capitalists to better realize their interests than is possible by simply extracting concessions through confrontation (Wright, 2013: 13).

Whether the Marikana massacre was the turning point that will lead to labour developing the strategic capacity to construct a positive class compromise remains to be seen. On 4 November 2014, a gathering of all the major industrial relations actors took place at NEDLAC under the leadership of the country's deputy president, Cyril Ramaphosa. It was agreed that "strike action by workers and trade unions is a constitutionally enshrined right. The right to strike is a legitimate exercise of power to pursue demands and strikes are also a measure of last resort" (NEDLAC Ekurhuleni Declaration, 2014: 2). Since then there have been ongoing consultations behind the scenes in NEDLAC and ongoing debates in Parliament over possible amendments to the legislation on strikes.

But if the proposals made in this article to strengthen the organisational/associational power of unions and reconnect this to institutional power are to be feasible, then the deeper structural violence that we suggested lies at the heart of the violence will need to be addressed in a more systematic way.. Increasingly there is a recognition in the pubic discourse in South Africa, expressed through the demand for "radical economic transformation", that the distribution of economic power (rather than the unequal distribution of capabilities) is the leading causal factor driving violence. This perspective requires that the distribution of economic power be addressed head-on, and requires a bolder and more integrated approach combining inclusive growth strategies, substantial social protection, capability development and labour activation at a scale sufficient to reconfigure structural deficiencies in the distribution of power (Roberts and Makhaya,2013).

The alternative to a more radical redistribution of power is the marginalisation of labour as it fragments under the pressure of neo-liberal globalisation and political factionalism. This could lead to a return to the adversarialism of the apartheid period. This will encourage government and employers to roll back some of the rights workers have won and the subordination of labour to the ruling party. South Africa's industrial relations system is at the crossroads; the battle over the rights won by labour in post-apartheid South Africa is being intensified as the political realignment following Marikana reshapes South Africa's political landscape.

Global Labour Journal, 2017, 8(2), Page 154 


\section{REFERENCES}

Adler, G. and E. Webster (1995) Challenging Transition Theory: The Labour Movement, Radical Reform and the Transition to Democracy in South Africa. Politics and Society, 23(1): 75-106.

Alexander, P. (2010) Rebellion of the Poor: South Africa's Service Delivery Protests - A Preliminary Analysis. Review of African Political Economy, 37(123): 24-40.

Alexander, P., T. Lekgowa, B. Mmope, L. Sinwell and B. Xezwi (2012) Marikana: A View from the Mountain and a Case to Answer. Johannesburg: Jacana.

Alexander, P. and P. Pfaffe (2013) Social Relationships to the Means and Ends in South Africa's Ongoing Rebellion of the Poor. The Balfour Insurrections. Social Movement Studies: Journal of Social, Cultural and Political Protest, 13(2): 204-221.

Andrew Levy (2014) The Wage Settlement Survey, Quarterly Report. Johannesburg: Andrew Levy Employment Publications.

Arias, E.D. and D.M. Goldstein (eds.) (2010) Violent Democracies in Latin America. Durham: Duke University Press.

Barrett, J. (2016) Building Solidarity in South Africa between Traditional Trade Union Members and Vulnerable Workers. Paper prepared for the "Decent Work and Development" cluster at the Society, Work and Development Institute (SWOP), University of the Witwatersrand, Johannesburg.

Bond, P. (2000) Elite Transition: Apartheid to Neoliberalism in South Africa. London: Pluto Press.

Brinkmann, U., H. Choi, R. Detje, K. Dörre, H. Holst, S. Karakayali and C. Schmalstieg (2008) Strategic Unionism: Aus der Krise zur Eineuerung. Wiesbaden: Springer.

Buhlungu, S. (2001) Democracy and Modernisation in the Making of the South African Trade Union Movement: The Dilemma of Leadership, 1973-2000. Unpublished PhD thesis, University of the Witwtsersrand, Johannesburg.

Buhlungu, S. (ed.) (2006) Taking Democracy Seriously: A Survey of Cosatu Members. Cape Town: HSRC Press.

Chinguno, C. (2013) Marikana Massacre and Strike Violence Post-apartheid. Global Labour Journal, 4(2): 160_ 166.

Chinguno, C. (2015) The Shifting Dynamics of the Relations between Institutionalisation and Strike Violence; A Case Study of Impala Platinum, Rustenburg (1982-2012) Unpublished $\mathrm{PhD}$ Dissertation, University of the Witwatersrand, Johannesburg.

Dörre, K., H. Holst and O. Nachtwey (2009) Organizing - A Strategic Option for Trade Union Renewal? International Journal of Action Research, 5(1): 33-67.

Du Toit, D., D. Bosch, D. Woolfrey, S. Godfrey, J. Rossouw, S. Christie, G. Cooper and C. Bosch (2003) Labour Relations Law: A Comprehensive Guide. Durban: LexisNexis Butterworths.

Ensor, L. (2016) State and Unions Clash on Ballots. Business Day, 17 February.

Fine, B. and Z. Rustomjee (1996) The Political Economy of South Africa: From Minerals-Energy Complex to Industrialisation. London: Westview.

Grzanka, P. (2014) Intersectionality: A Foundations and Frontiers Reader. Boulder: Westview Press.

Hyman, R. (1972) Strikes. London: Fontana/Collins.

Jewkes, R., N. Christofides, L. Vetten, R. Jina, R. Sigsworth and L. Loots (2009) Medico-legal Findings, Legal

Global Labour Journal, 2017, 8(2), Page 155 
Case Progression, and Outcomes in South African Rape Cases: Retrospective Review. (Beyrer, C. academic editor). PLoS Med. 2009 October; 6(10): e1000164. Available online at http://europepmc.org/articles/PMC2752115 [accessed 18 September 2016].

Kane-Berman, J. (2013) We Need our own Thatcher to Handle our Toxic Trade Unions. Business Day, 15 April, p. 9. Available online at: http://www.bdlive.co.za/opinion/2013/04/15/we-need-our-ownthatcher-to-handle-our-toxic-trade-unions [accessed 2 February 2015].

Lekalake, R. (2016) Support for Democracy in South Africa Declines amid Rising Discontent with Implementation. Afrobarometer, Dispatch Nom 71. Cape Town: Institute of Justice and Reconciliation.

Lévesque, C. and G. Murray. (2010) Understanding Union Power: Resources and Capabilities for Renewing Union Capacity. Transfer: European Review of Labour and Research, 16(3): 333-350.

Lutz, H., M.T.H. Vivar and L. Supik (2011) Framing Intersectionality: Debates on a Multi-faceted Concept in Gender Studies. Farnham: Ashgate.

Malala, J. (2013) We could use an iron Zulu. The Times, April 8. Available online at http://www.timeslive.co.za/opinion/columnists/2013/04/15/we-could-use-an-iron-zulu [accessed 4 February 2015].

Marrian, N. (2014) Numsa Set on Expansion of Scope despite Cosatu Objection. Business Day, 19 September, p. 3.

McGuire, D. (2012) Global and Local Union Struggles against the GATS: An Assessment of the Opportunity and Capacity for Unions to Influence International Trade Policy. Unpublished PhD dissertation, University of Kassel, Germany.

Mosoetsa, S. (2012) What Would You Do if the Government Fails to Deliver? Cosatu Members' Attitudes towards Service Delivery. In Cosatu's Contested Legacy: South African Trade Unions in the Second Decade of Democracy, edited by S. Buhlungu and M. Tshoaedi. Cape Town: HSRC Press.

National Economic Development and Labour Council (NEDLAC) (2014) NEDLAC Ekurbuleni Declaration. Johannesburg.

Nicolson, G. (2014) Marikana: Sceptical Miners await an end to the Farlam Commission. Daily Maverick. Available online at www.dailymaverick.co.za/article/2014-09-25-marikana-sceptical-miners-await-an-endto-the-farlam-commission [accessed 30 September 2014]

North, D. (1990) Institutions, Institutional Change and Economic Performance. Cambridge: Cambridge University Press.

O'Meara, D. (1975) The 1946 African mine workers' strike and the political economy of South Africa. Journal of Commonwealth and Comparative politics 13(2): 146-173.

Przeworski, A. (1985) Capitalism and Social Democracy. Cambridge: Cambridge University Press.

Roberts, S and G. Makhaya (2013) Expectations and Outcomes: Considering Competition and Corporate Power in South Africa. Review of African Political Economy, 138: 556-579.

Simpson, G. and E. Webster (1991) Crossing the Picket Line: Violence in Industrial Relations in South Africa. Industrial Relations Journal of South Africa, 11(4): 12-24.

Sinwell, L. and S. Mbatha (2013) Commemorating Marikana: The Spirit of Mambush Lives On. Amandla, No. 32 (Oct-Nov): 32-33.

Statistics South Africa (2015) Crime Statistics Series Volume III: Exploration of Selected Contact Crimes in South Africa and In-depth Analysis of Victims of Crime Survey Data: 2011-2014/15. Available online at 
www.statssa.gov.za/publications/Report-03-40-01/Report-03-40-012015.pdf_[accessed 12 May 2016].

Thakali, T. and M. Merten (2015) People do not Trust Zuma, Survey. The Star, 25 November: p. 10.

Venter, R. and A. Levy (eds.) (2011) Labour Relations in South Africa. Cape Town: Oxford University Press.

Von Holdt, K. (2010) Institutionalisation, Strike Violence and Local Moral Orders. Transformation: Critical Perspectives on Southern Africa, 72/73: 127-151.

Von Holdt, K. (2013a) The Violence of Order, Orders of Violence: Between Fanon and Bourdieu. Current Sociology, 61(2): 112-131.

Von Holdt, K. (2013b) The Transition to Violent Democracy in South Africa. Review of African Political Economy, 138: 589-604.

Webster, E. (1978) Essays in Southern African Labour History. Johannesburg: Ravan.

Webster, E. (1988) The Rise of Social Movement Unionism: The Two Faces of the Black Trade Union Movement in South Africa. In State Resistance and Change in South Africa, edited by P. Frankel, N. Pines and M. Swilling. North Ryde, NY, and Kent: Croom Helm.

Webster, E. (1999) Defusion of the Molotov Cocktail in South African Industrial Relations: The Burden of the Past and the Challenge of the Future. In Colonialism, Nationalism and Institutionalization of Industrial Relations in the Third World, edited by S. Kuruvilla and B. Mundell. Stamford, CT: JAI Press.

Webster, E. (2005) New Forms of Work and the Representational Gap. In Beyond the Apartheid Workplace: Studies in Transition, edited by E. Webster and K. von Holdt. Pietermaritzburg: University of KwaZuluNatal Press.

Webster, E. (2013) The Promise and the Possibility: South Africa's Contested Industrial Relations Path. Transformation, 81/82: 208-235.

Webster, E., K. Joynt and A. Metcalfe (2013) Repositioning Peak-level Social Dialogue in South Africa: Nedlac into the Future. Johannesburg: National Economic Development and Labour Council.

Wilderman, J. (2017) From Flexible Work to Mass Uprising: The Western Cape Farm Workers' Struggle. In Crossing the Divide: Precarious Work and the Future of Labour, edited by E. Webster, A.O. Britwum and S. Bhowmik. Pietermaritzburg: University of KwaZulu-Natal Press.

Wright, E.O. (2000) Working-class Power, Capitalist-class Interests, and Class Compromise. American Journal of Sociology, 105(4): 957-1002.

Wright, E.O. (2013) Class Struggle and Class Compromise in the Era of Stagnant Economies. Transform! European Network for Alternative Thinking and Political Dialogue, Journal, 11/2012: 1-15.

\section{Interviews}

Anonymous interview with senior Human Resource Manager, Johannesburg, 10 February 2014.

Kriel, A. (2014) Author telephonic interview with Andre Kriel, general secretary, Southern African Clothing and Textile Workers Union (SACTWU). Johannesburg, 4 February 2014. 


\section{BIOGRAPHICAL NOTE}

EDWARD WebSTER is Professor Emeritus in the Society Work and Development Institute (SWOP) at the University of the Witwatersrand. His recent publications include: Webster, E. and K.

Pampallis (eds.) (2017) The Unresolved National Question: Left Thought under Apartheid, Wits University Press; and Webster, E, A.O. Britwum and S. Bhowmik (eds.) (2017) Crossing the Divide; Precarious Work and the Future of Labour, University of KwaZulu-Natal Press.

[Email: Edward.Webster@wits.ac.za] 